\title{
Strukturalne przemiany na Śląsku wywołane akcją kolonizacyjną na przykładzie biskupiego księstwa nyskiego
}

\section{Winfried Schich, Joachim Stephan}

W niniejszym artykule mapy pełnią dwie istotne funkcje ${ }^{1}$. Po pierwsze i najważniejsze, są one narzędziem badawczym służącym do rekonstrukcji kolonizacji konkretnego regionu albo ziemi w Europie Środkowej. Po drugie, stanowią graficzną prezentację wyników naszych badań. Zastosowana przez nas metoda badawcza polega na zbieraniu dla pojedynczych miejscowości danych dostarczonych przez różnie dyscypliny naukowe, naniesieniu ich na mapę, a następnie poddaniu analizie według metody opracowanej przez grupę badawczą Germania Slavica na Freie Universität w Berlinie w latach 70. i 80. ubiegłego wieku².

Pojęcie „Germania Slavica” zostało ukute i wprowadzone do terminologii badawczej przez Wolfganga H. Fritzego ${ }^{3}$. Tym terminem, który został stworzony w analogii do pojęcia „Germania Romana" ukutego przez językoznawcę germanistę Theodora Fringsa, Wolfgang Fritze określit przestrzeń, w której ludność słowiańska w efekcie długotrwałego procesu była językowo germanizowana ${ }^{4}$. W przeciwieństwie do głównego nurtu niemieckiej historiografii, skupionego na kolonizacji niemieckiej, autor ten stawiał

\footnotetext{
${ }^{1}$ Artykuł prezentuje tezy wygłoszone podczas naszego wystąpienia na XIX Powszechnym Zjeździe Historyków Polskich w Szczecinie dnia 17 września $2014 \mathrm{r}$. Tekst referatu został poszerzony i opatrzony przypisami. Obszerne opracowanie problematyki pt. Strukturelle Veränderungen in Schlesien durch den mittelalterlichen Landesausbau am Beispiel des Breslauer Bistumslandes Neisse-Ottmachau zostanie opublikowane w czasopiśmie „Jahrbuch für die Geschichte Mittel- und 0stdeutschlands" w $2016 \mathrm{r}$.

20 historii pojęcia i grupy badawczej Germania Slavica zob.: W. Schich Germania Slavica. Die ehemalige interdisziplinäre Arbeitsgruppe am Friedrich-Meinecke-Institut der Freien Universität Berlin, „Jahrbuch für die Geschichte Mittel- und Ostdeutschlands", 48, 2002, s. 269-297.

3 W Polsce to przede wszystkim Jerzy Strzelczyk pisał na temat idei projektu i 0 sposobach jej realizacji. Zob..J. Strzelczyk, Problemy badań nad zachodnią peryferią osadnictwa stowiańskiego w Niemczech, w: Stowiańszczyzna połabska między Niemcami a Polską, red. J. Strzelczyk, Poznan 1981, s. 183-199; tenże, Germania Slavica, „Slavia Occidentalis”, 37, 1980, s. 178-180; tenże, Średniowieczna Brandenburgia (Przegląd nowszych publikacji), ,Studia Historica Slavo-Germanica”, 10, 1981, s. 159-198.
}

jednak w centrum uwagi badacza nie tyle same procesy kolonizacyjne, co raczej kształtowanie się przestrzeni zamieszkałej przez ludność słowiańską zarówno przed okresem kolonizacji średniowiecznej, jak i w czasach późniejszych. Naturalnie początkowo główny nacisk położono na historię osadnictwa, która nie stanowiła jednak celu samego w sobie, lecz według zaleceń szkoły Rudolfa Kötzschkego miała dostarczać nowej wiedzy o historii ustrojus. Ponieważ same źródła pisane nie wystarczyły, aby wyjaśnić rolę ludności słowiańskiej w historii wschodnich Niemiec, metodyka tego nurtu od początku była interdyscyplinarna i uwzględniała badania archeologiczne oraz onomastykę.

Podczas prac korzystano także z pomocy kartografii. Nowa metoda została wypróbowana podczas tworzenia mapy Osadnictwo przedkolonizacyjne $i$ w epoce petnego średniowiecza $w$ Suchej $i$ Wysokim Teltowie do Atlasu historycznego Brandenburgii i Berlina, który wydano w 1977 r. ${ }^{6}$ Na mapę z danymi hydrograficznymi i geomorfologicznymi naniesiono wówczas najważniejsze informacje pochodzące ze źródeł pisanych, archeologicznych i onomastycznych.

\footnotetext{
4 „Denjenigen Raum, innerhalb dessen die slawische Bevölkerung in einem allmählichen Prozeß sprachlich germanisiert worden ist, bezeichnen wir als »Germania Slavica«, d. i. ein Raum, in dem ein Volkstum deutscher Sprache sich ein Volkstum slawischer Sprache assimiliert hat”. W.H. Fritze, Die IAG „GERMANIA SLAVICA”, [mps, 5 września 1980], cyt. za: W. Schich, „Germania Slavica”, s. 273.

5 Rudolf Kötzschke był w 1. poł. XX w. jednym z czołowych przedstawicieli interdyscyplinarnej historii regionalnej (Landesgeschichte) w Niemczech, skupionej przede wszystkim na badaniach historii osadnictwa. Zob. 100 Jahre Landesgeschichte (1906-2006). Leipziger Leistungen, Verwicklungen und Wirkungen, Hrsg. E. Bünz, Leipzig 2012 (Schriften zur sächsischen Geschichte und Volkskunde, 38).

6 W.H. Fritze, W. Schich, Vorkoloniale und hochmittelalterliche Besiedlung der Zauche und des Hohen Teltow, Berlin 1977 (Historischer Handatlas von Brandenburg und Berlin, 4, 56); W. Schich, Zum Verhältnis von slawischer und hochmittelalterlicher Siedlung in den Landschaften Zauche und Teltow, „Jahrbuch für die Geschichte Mittel- und Ostdeutschlands", 26, 1977, s. 53-85.
} 
Jej interpretacja pozwoliła stwierdzić, że osadnictwo słowiańskie było skoncentrowane w okolicach naturalnych zbiorników wodnych, zaś osadnictwo doby kolonizacji nawiązało do starszych struktur i przesuwało się z czasem na wyżej potożone tereny. W drugiej fazie kolonizacji osady z czasów przedkolonizacyjnych i z pierwszej fazy kolonizacji zostały zrestrukturyzowane i na do tej pory niezasiedlonych morenach dennych powstały rozległe wsie. Mapy miały również istotne znaczenie w innych projektach zespołu Germania Slavica, m.in. tych dotyczących wschodniej części Prignitz ${ }^{7}$ i ziemi hawelskej ${ }^{8}$.

W celu przedstawienia opisanej powyżej metody jako obszar badawczy wybraliśmy biskupie księstwo nyskie, które wcześniej było kasztelanią otmuchowską, od dawna należącą do uposażenia biskupstwa wrocławskiego?. Główną przyczyną wyboru tego regionu była bardzo bogata baza źródeł historycznych, która zachowała się dla tych terenów. Wielu przywilejom lokacyjnym towarzyszą dwa rejestry z pocz. XIV i pocz. $\mathrm{XV}$ w., które wymieniają prawie wszystkie miejscowości tego regionu i ich przynależność do centrów administracyjnych (districtus) ${ }^{10}$. Źródło z pocz. XIV w., tzw. Liber fundationis ${ }^{11}$, podaje przede wszystkim liczbę łanów znajdujących się w każdej wsi, zaś młodszy rejestr - różnego rodzaju dochody biskupa $\mathrm{w}$ poszczególnych wsiach ${ }^{12}$. Obydwa źródła zawierają cenną listę wsi na prawie polskim. Rejestr z pocz. XV w. pozwala opisać lepiej niektóre zjawiska, które w starszym nie zostały dostatecznie udokumen-

7 W.H. Fritze, Eine Karte zum Verhältnis der frühmittelalterlich-slawischen zur hochmittelalterlichen Siedlung in der Ostprignitz, w: Germania Slavica II, Hrsg. W.H. Fritze, Berlin 1981 (Berliner Historische Studien, 4), s. 41-92.

8 Das Havelland im Mittelalter. Untersuchungen zur Strukturgeschichte einer ostelbischen Landschaft in slawischer und deutscher Zeit Hrsg. W. Ribbe, Berlin 1987 (Germania Slavica, 5; Berliner Historische Studien, 13).

9 Kasztelania otmuchowska została określona jako „patrimonium speciale" w bulli papieża Hadriana IV z 1155 r., potwierdzającej prawa i własności biskupstwa. Schlesisches Urkundenbuch, [dalej: SUB], Bd. 1, Bearb. H. Appelt, Köln 1963, nr 21. Kwestią sporną jest jednak, od kiedy kasztelania należała do biskupstwa. Zob. E. Wółkiewicz, Patrimonium sancti Iohannis. U początków władztwa biskupiego w ziemi otmuchowsko-nyskiej, w: Milicz. Clavis Regni Poloniae. Gród na pograniczu, red. J. Kolenda, Wrocław 2008, s. 225-234; T. Jurek, Ryczyn biskupi. Studium z dziejów Kościoła polskiego w XI w., „Roczniki Historyczne", 60, 1994, s. 21-66. towane. Przede wszystkim pokazuje on jednak zmiany w strukturach administracyjnych w XV w. oraz zjawisko opuszczania wsi, które można obserwować przede wszystkim w górach, gdzie położenia wielu miejscowości nie da się zrekonstruować.

Przyczyną tak wyjątkowego bogactwa danych jest fakt, że w XIII w. biskupom udało się za pomocą kolonizacji i modernizacji starych struktur stworzyć terytorium, na którym po ciężkich walkach z książętami śląskimi sprawowali niepodzielną władzę. Ta sytuacja spowodowała, że dokumenty wytworzone przez administrację kościelną wymieniają wszystkie miejscowości tego regionu. Tym sposobem Liber fundationis z pocz. XIV w. daje nam znakomity obraz ziemi nyskiej bezpośrednio po zakończeniu kolonizacji i stanowi doskonałą podstawę do opracowania map tematycznych dotyczących tego regionu.

Na mapę zostały naniesione dwie podstawowe informacje z Liber fundationis: przynależność miejscowości do centrum administracyjnego i położenie wsi na prawie polskim. W ujęciu chronologicznym proces kolonizacyjny $\mathrm{w}$ biskupim księstwie nyskim - który można rekonstruować na podstawie wielu przywilejów lokacyjnych i który został przedstawiony na mapie - kształtuje się w dużym uproszczeniu następująco ${ }^{13}$. Przed 1223 r. Nysę założono na prawie flamandzkim w południowo-wschodniej części kasztelanii, na skrzyżowaniu dwóch tras komunikacyjnych: drogi prowadzącej w kierunku południowo-wschodnim na Morawy oraz traktu

$10 \mathrm{~J}$. Pfitzner, Besiedlungs-, Verfassungs- und Verwaltungsgeschichte des Breslauer Bistumslandes, T. 1: Bis zum Beginn der böhmischen Herrschaft, Reichenberg 1926. Zob. też: B.W. Scholz, Das geistliche Fürstentum Neisse. Eine ländliche Elite unter der Herrschaft des Bischofs (1300-1650), Köln i in. 2001 (Forschungen und Quellen zur Kirchen- und Kulturgeschichte Ostdeutschlands, 42). 0 znaczeniu terminu „districtus”, który w śląskich źródłach często oznacza Weichbild, zob. A. Gąsiorowski, „Districtus” w Wielkopolsce początków XIV wieku (Z zagadnień zarządu terytorialniego Polski średniowieczniej), „Roczniki Historyczne”, 32, 1966, s. 173-193.

11 Liber fundationis episcopatus Vratislaviensis [dalej: Lib. fund.], Hrsg. H. Markgraf, J.W. Schulte, Breslau 1889 (Codex diplomaticus Silesiae, 14).

12 W. Schulte, Quellen zur Geschichte der Besitzverhältnisse des Bistums Breslau, w: Studien zur schlesischen Kirchengeschichte [dalej: młodszy rejestr], Breslau 1907 (Darstellungen und Quellen zur schlesischen Geschichte, 3), s. 204-260.

130 historii kolonizacji zob. J. Pfitzner, Besiedlungs-, Verfassungs- und Verwaltungsgeschichte, s. 48-94. 


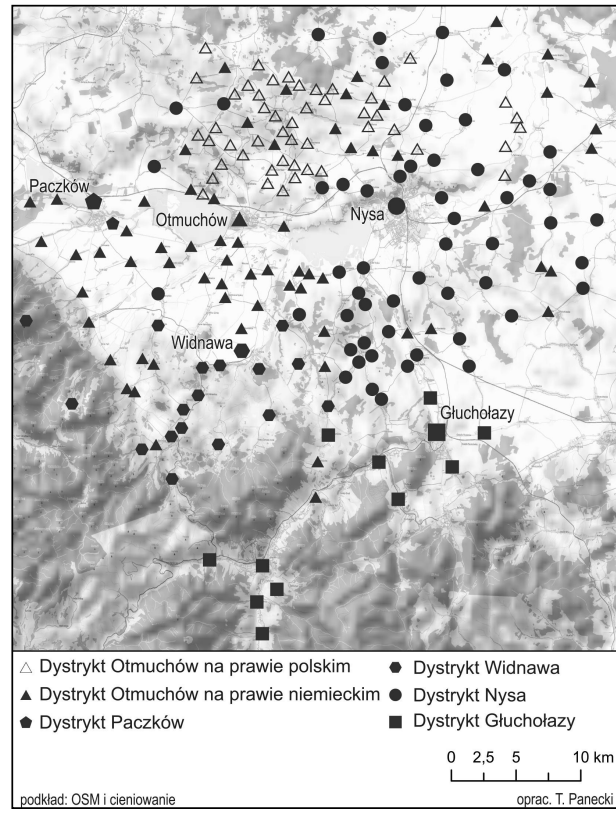

Mapa 1. Księstwo nyskie w XV w.

wiodącego na południe, przez tereny górskie do centrów górnictwa (w konkurencji do margrabiów morawskich, którzy dotarli do tych terenów z południa). Prawdopodobnie w latach 30 . tego wieku nastąita lokacja pierwszych nowych wsi: Jędrzychowa (Heidersdorf) i Konradowa (Konradsdorf) oraz unowocześnienie struktur prawnych i przestrzennych polskich wsi Biała Nyska (Bielau) i Przetęk (Preiland) w okolicach Nysy ${ }^{14}$. Już w 1237 r. wsie koło Nysy służyły jako wzór dla nowych osad nad rzeką Rimane w północnej części terytorium księstwa nyskiego ${ }^{15}$.

Przed 1232 r. - w czasach biskupa Wawrzyńca (1207-1232) - powstała oś osadnictwa w górę rzeki Białej (Biele) do miasta i Weichbildu Głuchołazy (Ziegenhals). Jak informuje nas późniejszy dokument z 1263 r., biskup Wawrzyniec przekazał swojemu wójtowi Witigowi tereny nad górnym biegiem rzeki Biała, aby rozbudował on obszar przygraniczny kasztelanii otmuchowskiej

14 SUB III, nr 190; J. Pfitzner, Besiedlungs-, Verfassungs- und Verwaltungsgeschichte, s. 72.

15 SUB II, nr 128; Regesten zur schlesischen Geschichte, t. 1-4 [dalej: SR], Hrsg. C. Grünhagen, K. Wutke, Breslau 1884-1892 (Codex diplomaticus Silesiae, 7, 1-3, 16). (jako konkurencji dla Moraw) ${ }^{16}$. Osadnictwo pełniło tu również funkcję zabezpieczenia granicy, co w przypadku instytucji kościelnych było w tym czasie zjawiskiem dość powszechnym.

W 1236 r. nabyto osadę targową Ścinawa Mała (Steinau) na granicy wschodniej terytorium biskupiego, a w 1243 r. przekształcono ją w siedzibę wójtostwa ${ }^{17}$. Tereny leśne na wschód od rzeki Białej powyżej wsi Stary Las (Altewalde) zostały zasiedlone w 1249 r. $^{18}$ Ścinawa Mała była na pocz. XIV w. centrum dystryktu o tej samej nazwie, leżącego między rzekami Nysa i Biała, który już w 1284 r. był całkowicie zasiedlony ${ }^{19}$. Od tych terenów wokół rzeki Biała poczynając, osadnictwo rozprzestrzeniało się dolinami w kierunku zachodnim. Być może wieś Biskupów (Bischofswalde) stworzyła rodzaj bramy do lasu granicznego, do którego biskup rościł sobie prawo.

W 1248 r. na zachodzie księstwa nyskiego rozpoczęto zasiedlanie doliny rzeki Vilchicha (Wildschützer Bach) na prawie niemieckim z przewagą osadników polskich ${ }^{20}$. Parę lat późnej, w 1254 r., miało miejsce lokowanie miasta Paczków (Patschkau) jako centrum ekonomicznego dla wsi biskupich leżących w części południowo-zachodniej tego terytorium ${ }^{21}$. Z lat 60 . XIII w. pochodzą pierwsze wzmianki o przeniesieniu wsi z pra-wa polskiego na niemieckie: Buków (Baucke) w 1260 r., Ligota Górna (Ellguth) w 1261 r. ${ }^{22}$ Już kilka lat późnej kolonizacja sięgała terenów górskich. Przed $1267 \mathrm{r}$. nastąiła lokacja miasta i Weichbildu Jeseník (Freiwaldau) położonych na wysokości $432 \mathrm{~m}$ n.p.m. ${ }^{23}$ Główna jego funkcja nie była związana ze stworzeniem rynku dla pobliskich wsi, lecz $\mathrm{z}$ rozwojem górnictwa.

Nieco później, w 1268 r., książę śląski lokował w konkurencji do polityki biskupa miasto

\footnotetext{
16 SUB III, nr 449; SR III, nr 1168.

17 SUB II, nr 120, 175, 244.

18 Tamże, nr 380; SR I, nr 705.

19 SUB V, nr 117, 135.

20 W tym roku rycerz Wrociwoj dostał na tych terenach 40 tanów leśnych z obowiązkiem lokowania tam Polaków na prawie niemieckim. SUB II, nr 352.

21 SUB III, nr 112; SR IV, nr 864

22 SUB III, nr 309, 375.

23 SUB IV, nr 34; SR II, nr 1276.
} 
i Weichbild Vidnava (Weidenau) ${ }^{24}$. Rywalizacja między biskupem i księciem doprowadziła w latach 80 . do otwartej walki. Książę zajął około sześćdziesięciu wsi, które według niego biskup bezprawnie lokowal na terenie lasu granicznego (przesieki). W 1290 r. biskup wygrał spór z księciem i założył w Nysie sąd apelacyjny dla wszystkich wsi na prawie niemieckim znajdujących się na terytorium nysko-otmuchowskim ${ }^{25}$.

W ten sposób na podstawie bogatych źródeł pisemnych można rekonstruować procesy kolonizacyjne, których rezultaty zostały zapisane w rejestrze biskupim z pocz. XIV w. Poza przywilejami lokacyjnymi i rejestrami mamy jeszcze jeden wyjątkowy dokument, który powstał podczas sporu z księciem o tereny przygraniczne. W 1284 r. biskup zażądał od niego zwrotu około 60 wsi na prawie niemieckim (villae Teutonicales względnie villae maximae) wymienionych $\mathrm{z}$ nazwy, które książę zajął, twierdząc, że biskup bezprawnie lokowat je w lesie granicznym należącym do niego (in fundo nostre presece) ${ }^{26}$.

$\mathrm{Na}$ mapie wsi ulokowanych w przesiece widać, że ciągnęła się ona od wschodu do południa Nysy, czyli na terenach, na których kolonizacja miała miejsce przede wszystkim w XIII w. W źródle z 1284 r. pojawia się dużo wsi z nazwami polskimi, co potwierdza fakt, że las był kolonizowany również przez osadników polskiego pochodzenia. Interpretację tę wspierają także niektóre źródła pisane, w których znajduje się duża liczba podwójnych nazw. Same toponimy nie mogą służyć jako dowód osadnictwa przedkolonizacyjnego, jednakże wskazują one na istnienie w okolicy przesieki polskiego osadnictwa i na wspólistnienie na tym terenie Polaków i Niemców. Prawdopodobnie to Polacy nadawali nowym osadom nazwy nawiązujące

24 J. Pfitzner, Besiedlungs-, Verfassungs- und Verwaltungsgeschichte, s. 81; W. Kuhn, Herzogs- und Adelssiedlung im Neisser Bistumsland, w: tenże, Neue Beiträge zur schlesischen Siedlungsgeschichte. Eine Aufsatzsammlung, Sigmaringen 1984 (Quellen und Darstellungen zur schlesischen Geschichte, 23), s. 90 i przyp. 16 (wyd. 1: 1975).

25 SUB V, nr 452, 490; SR III, nr 2141.

26 SUB V, nr 122, 127. Na temat przesieki zob.: B. Miśkiewicz, Przesieka, w: Stownik starożytności stowiańskich [dalej: SSS], red. G. Labuda, Z. Stieber, t. 4, Wrocław 1970, s. 389-390; J. Leśny, Zasieki, w: SSS, t. 7, s. 76-82

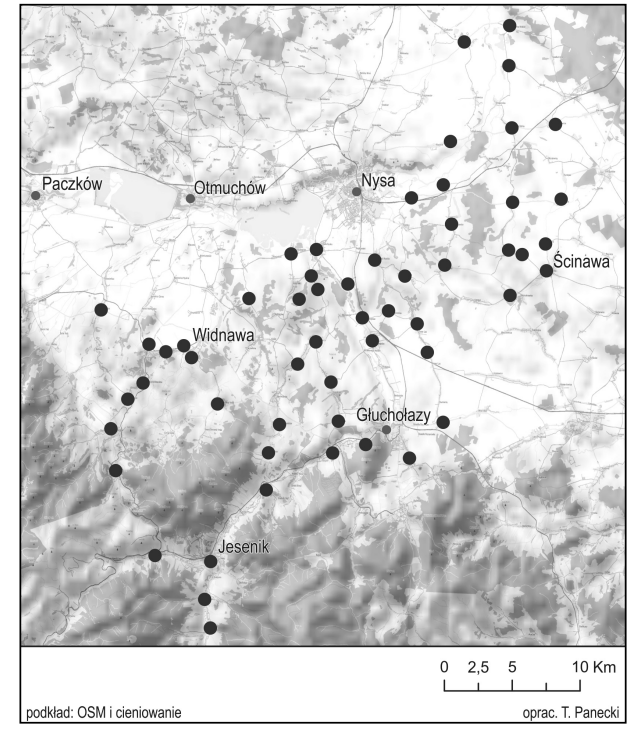

Mapa 2. Wsie w przesiece w 1284 r.

do starych toponimów. Tereny powyżej wysokości $250 \mathrm{~m}$ n.p.m. zostały zasiedlone dopiero w XIII w. Późniejsze źródła pokazują w tym miejscu zwartą grupę wsi z łanami leśnymi, charakterystycznymi dla osadnictwa zakładanego na surowym korzeniu.

Wrócimy jednak do rejestrów z XIV i XV w., dających nam wyjątkowo kompletny obraz średniowiecznego terytorium. Liber fundationis rozróżnia m.in. wsie na prawie niemieckim i polskim oraz daje informacje o ich przynależności do różnych centrów administracyjnych. Informacje o tym, że osady należały do miasta jako nowoczesnego centrum administracyjnego, wskazują na kolonizację tych terenów na prawie niemieckim. Wyjątkiem są niektóre części wsi należących do miasta Vidnavy (Weidenau), które nie wchodzity w skład Weichbildu ${ }^{27}$. Sfałszowany dokument, pochodzący rzekomo z 1291 r., daje wiarogodny spis 15 wsi należących do tego Weichbildu ${ }^{28}$. Na

\footnotetext{
27 W dystryktach zwanych Weichbild miasto było nie tylko miejscem, gdzie znajdował się rynek, ale także centrum sądowym. Weichbildy łączyły osadnictwo wiejskie i miejskie w jedną całość prawno-ekonomiczną. Zob. J. Menzel, Stadt und Land in der schlesischen Weichbildverfassung, w: Die mittelalterliche Städtebildung im südöstlichen Europa, Hrsg. H. Stoob, Köln-Wien 1977 (Städteforschung, A, 4), s. 19-38, szczeg. S. $25-35$.

28 SUB VI, nr 462.
} 
pocz. XIV w. dystrykt Vidnava liczył 59 osad położonych częściowo na północ od Paczkowa i Otmuchowa. Ekspansja tego dystryktu polegała prawdopodobnie na tym, że nowe jednostki osadnicze na prawie niemieckim potrzebowały miasta lokowanego na tym samym prawie, będącego dla nich zarazem centrum jurysdykcji. Wydaje się, że właśnie tym należy tłumaczyć fakt, iż nie przynależały one wówczas do pobliskiego centrum miejskiego Otmuchów, które nie miało

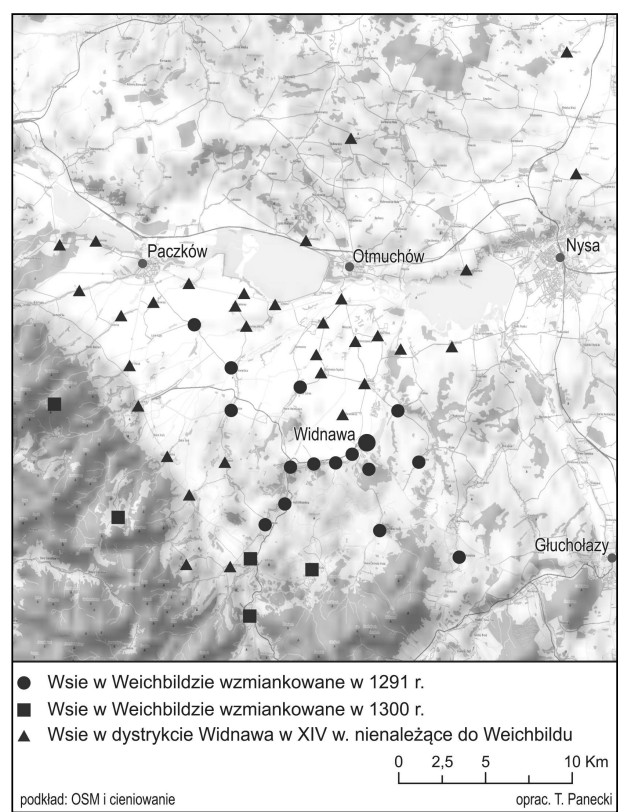

Mapa 3. Weichbild i dystrykt Widnawa

wtedy prawa niemieckiego. Nie jesteśmy jednak w stanie odpowiedzieć na pytanie, dlaczego nie został wówczas stworzony z tych wsi nowy Weichbild z centrum w Paczkowie.

Osobny problem dla wyjaśnienia genezy osadnictwa stanowią miejscowości oznakowane na mapie szarymi gwiazdkami. W starszym rejestrze nie przynależą one do konkretnego miasta, natomiast w rejestrze z XV w. wiązane są z Nysą. Nie jest jasne, jak należy rozumieć tę sytuację. Czy ok. 1300 r. w tym rejonie nie było jeszcze stałych struktur administracyjnych, czy też w Liber fundationis, którą znamy tylko z późniejszej kopii, brakuje po prostu fragmentu z tytułem rubryki?

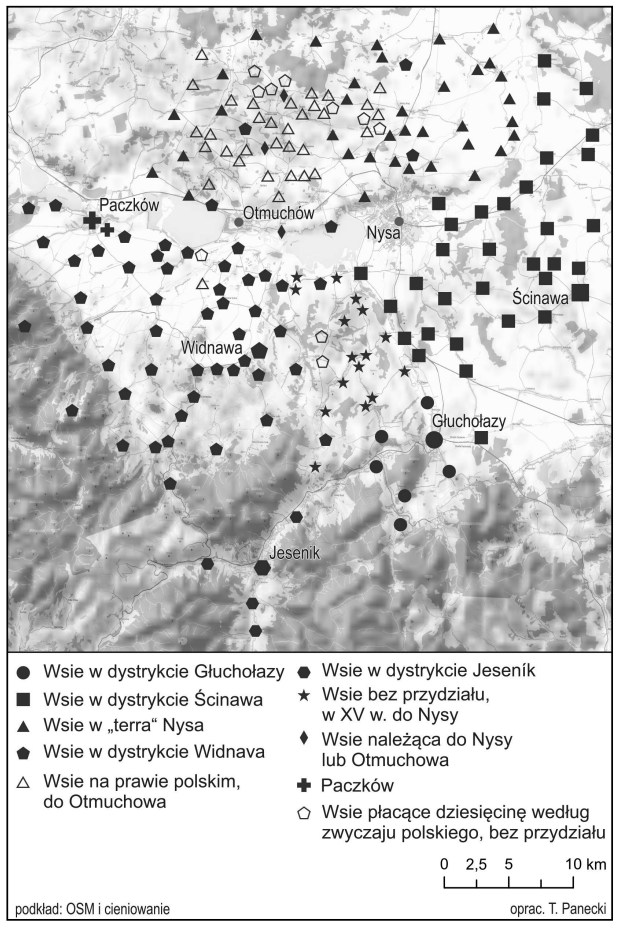

Mapa 4. Biskupie księstwo nyskie na pocz. XIV w.

Również na to pytanie aktualnie nie jesteśmy w stanie dać odpowiedzi.

Ogólnie rzecz biorąc, struktury prezentowane przez młodszy rejestr pochodzący z XV w. są prostsze: liczba centrów administracyjnych jest mniejsza, okręgi Ścinawa i Jeseník (Freiwaldau) zostały zlikwidowane, a Otmuchów (Ottmachau), który lokowano na prawie niemieckim w $1347 \mathrm{r}^{29}$, był już nie tylko centrum dla wsi na prawie polskim, ale również dla osad na prawie niemieckim. Młodszy rejestr dostarcza także mniej informacji o genezie osadnictwa niż starszy. W dokumencie tym można zauważyć już tendencję do tworzenia na badanym obszarze nowoczesnych struktur administracyjnych, które były uwarunkowane wymogami geograficznymi.

Liber fundationis pokazuje na terenie położonym na północ od Otmuchowa obszar względnie zamknięty z około czterdziestoma wsiami

29 Regesty Śląskie 1343-1348, oprac. K. Bobowski i in., Wrocław i in. 1975 , nr 671 . 


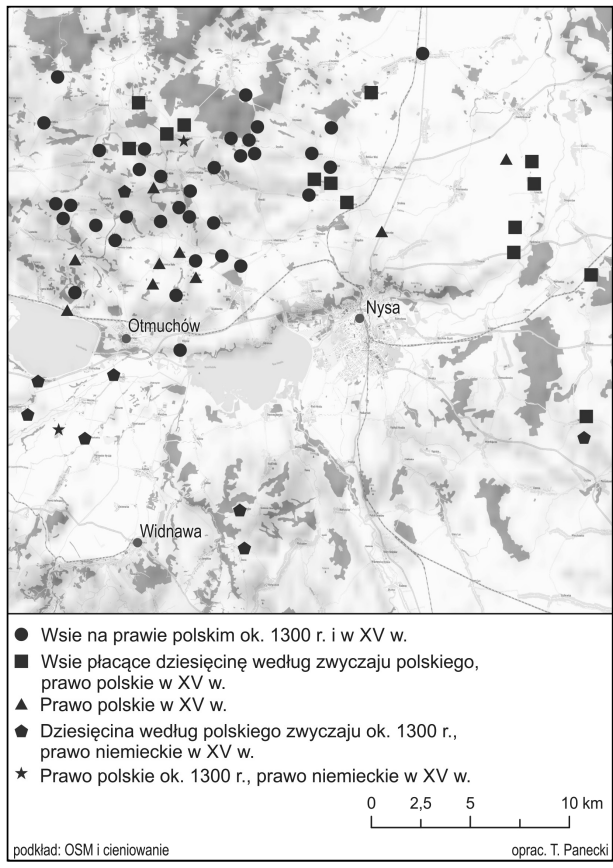

Mapa 5. Prawo polskie w księstwie nyskim

na prawie polskim bądź płacącymi dziesięcinę według starego zwyczaju. Ponieważ cechy te wskazują na stare osadnictwo, można się tu dopatrywać istnienia reliktów osadnictwa przedkolonizacyjnego.

Podobnie jak wymieniony już w Liber fundationis rejestr z pocz. $\mathrm{XV}$ w. rozróżnia wsie na prawie niemieckim i polskim oraz podaje przynależność konkretnych osad do centrum administracyjnego bądź sądowego. Mapa łączy informacje z tych dwóch źródeł i pozwala tym sposobem nie tylko identyfikować obszar reliktowy starszego osadnictwa, ale i uchwycić dalszy proces modernizacji struktur wiejskich. Nowo zakładane osady zawsze otrzymywały prawo niemieckie $\mathrm{z}$ tanami o dokładnie określonych wymiarach. W przypadku części polskich wsi doszło do modernizacji, która mogła odbywać się na dwa sposoby: albo wieś została pozostawiona na tym samym miejscu, albo łączyła się z innymi w jedną większą miejscowość na prawie niemieckim, tym samym zmieniając swoje położenie. Dobry przykład takiego scalenia wsi daje dyplom biskupa Jana z $1300 \mathrm{r}$, w którym opisano, jak biskup Tomasz II (12701292) - prawdopodobnie ok. 1290 r. - sprzedał pewnemu mieszkańcowi Nysy o imieniu Stefan (Stephan) 100 łanów flamandzkich i zobowiązał go do stworzenia z 6 polskich wsi położonych na tym obszarze (Nowaki, Slawneviz, Morawari, villa Ulrici, Cuchare oraz Radzicoviz) 1 wsi na prawie niemieckim ${ }^{30}$. Ponieważ Stefan nie miał dość środków finansowych, sprzedał później połowę tych łanów Gerardowi, który także był mieszkańcem Nysy. Biskup Tomasz dodał jeszcze kolejne 15 lanów i w 1300 r. nastąpiła lokacja 2 wsi na prawie niemieckim: utworzonej z 60 łanów wsi Stefana Radzicoviz, która już w 1307 r. była wymieniana jako Stephansdorf (Radzikowice), oraz utworzonej z 55 łanów wsi Gerarda Nowag (Nowaki). Obydwaj zasadźcy dostali również własne sołectwa. Przynajmniej 4 z 6 wsi na tym obszarze zostały opuszczone, a 2 rozbudowano, przy czym areał ziemi uprawnej powiększył się.

Przekształcenie polskich wsi mogło również następować stopniowo, poprzez wprowadzanie pojedynczych zmian charakterystycznych dla funkcjonowania wsi na prawie niemieckim. Jeżeli na przykład wieś na tym prawie płaciła dziesięcinę tradycyjną, można to interpretować jako relikt starego stanu prawnego. Na mapie nie widać jednak, żeby proces modernizacji był zawsze jednokierunkowy. Zdarzały się także sytuacje, że wsie, które otrzymywały prawo niemieckie, wracały do starego. Na przykład w 1373 r. na prośbę rycerza biskup zmienił prawo jego dóbr w Wilemowicach (Schützendorf) z niemieckiego na polskie, a rok później uczynił to samo w związku ze sprzedażą 2 lanów w Goszowicach (Kuschdorf) ${ }^{31}$.

Liber fundationis zawiera także cenne informacje o organizacji parafii w biskupim księstwie nyskim. Ogólnie tereny starszego osadnictwa cechuje istnienie parafii zajmujących duże obszary. Najstarsze kościoły parafialne znajdowały się zazwyczaj w centrach kasztelanii. Pojedyncze świątynie wiejskie, które podobne jak miejskie miały prawo do dziesięciny, można uznać za najstarsze w księstwie. Wsie, które powstały w epoce

30 SUB VI, nr 442; SR III, nr 2203, 2604, Stephansdorf 1307; SR IV, nr 2933.

31 K. Engelbert, Quellen zur Geschichte des Neisser Bistumslandes auf Grund der drei ältesten Neisser Lagerbücher, Würzburg 1964 (Quellen und Darstellungen zur schlesischen Geschichte, 10), nr 390, 484. 
kolonizacji, zwykle miały swój kościół, który posiadał jeden lub dwa łany na własność, w przeciwieństwie do starszych, otrzymujących dziesięcinę ze wsi parafialnych. Na mapie widać, że otmuchowski był prawdopodobnie najstarszym kościołem parafialnym, z którego powstały później nowe parafie. Wsie, które płaciły dziesięcinę, znajdują się przede wszystkim w obszarze starego osadnictwa oraz w dolinach wiodących do miast Głuchołazy (Ziegenhals) i Vidnavy (Weidenau).

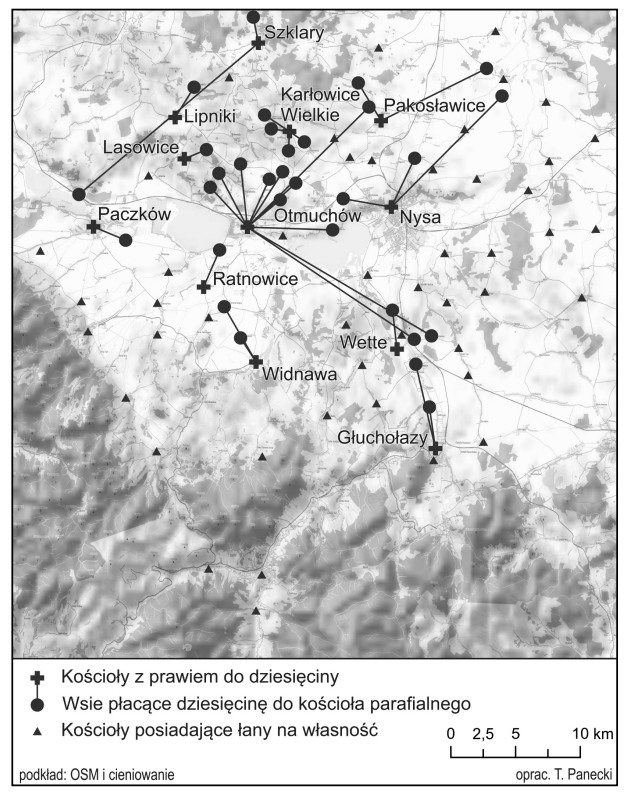

Mapa 6. Struktury kościelne

Kolejne ważne informacje o genezie osadnictwa dostarczone przez rejestry dotyczą liczby i rodzaju łanów w osadach badanego obszaru. Starsze osadnictwo cechuje się nieregularnymi i małymi formami, zaś osadnictwo na prawie niemieckim - wsiami i polami rozmieszczonymi w sposób regularny, np. ulicówka z lanami flamandzkimi, wieś leśno-łanowa itd. Kolonizacja na prawie niemieckim w badanych regionach używała przede wszystkim dwóch różnych typów łanów: większego - leśnego (ok. 24 ha) i mniejszego - flamandzkiego (ok. 16,8 ha) ${ }^{32}$. Istotna różnica dotyczyła również struktury samych łanów: cała powierzchnia łanu leśnego znajdowała się zawsze w jednym miejscu i stanowiła całość, powierzchnia łanu flamandzkiego mogła natomiast znajdować się na różnych polach, przez co nadawał się on lepiej do przemiany już istniejących pól lub do karczowania lasów między już istniejącymi osadami. $Z$ tego powodu ten ostatni typ łanu spotykany był przede wszystkim na terenach skolonizowanych. W rejestrze z XIV w. pojawia się łaciński termin mansus oznaczający lan, jednak brak przy nim informacji o jego wielkości czy charakterze. W dalszej części tekstu będziemy w stosunku do niego używać określenia „włóka zwyczajna” ${ }^{33}$. Wsie z takimi ła-

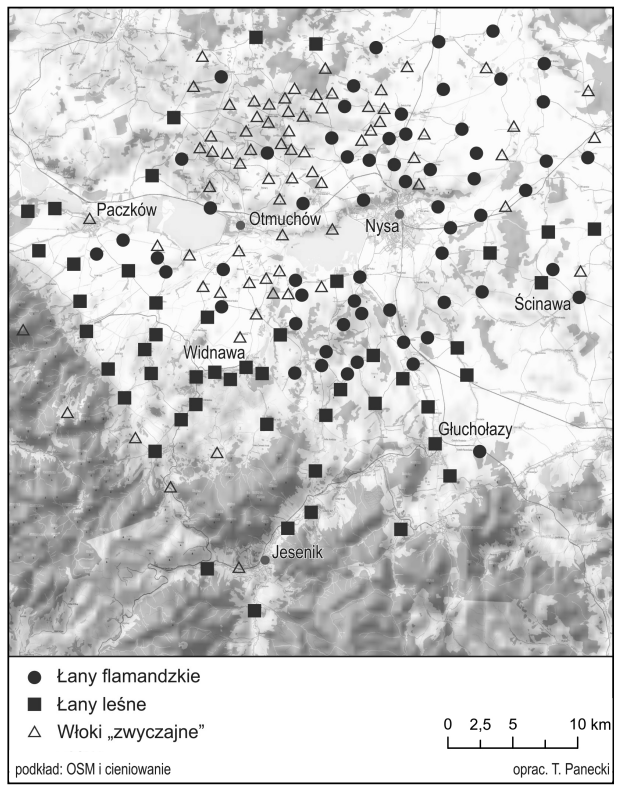

Mapa 7. Typy łanów

nami występowały przede wszystkim na obszarze starego osadnictwa, dlatego wydaje się nam, że ich powstanie trzeba wiązać $\mathrm{z}$ adaptacją starych struktur do nowoczesnego systemu podatkowego, przy jednoczesnym braku większych zmian struktury wsi i pól. Za tą hipotezą przemawia

\footnotetext{
32 Por. W. Kuhn, Flämische und fränkische Hufe als Leitformen der mittelalterlichen Ostsiedlung, w: tenże, Vergleichende Untersuchungen zur mittelalterlichen Ostsiedlung, Köln-Wien 1973 (Ostmitteleuropa in Vergangenheit und Gegenwart, 16), s. 1-51 (wyd. 1: 1960).

33 Antoni Musztyfaga interpretuje tany wielkie liczone za małe jako osobny typ łanu; nam jednak wydaje się, że chodzi tu nie 0 strukturę tanu, lecz o sposób płacenia za niego czynszu etc. Twierdzenia autora wydają się nam wątpliwe. A. Musztyfaga, Ze studiów nad osadnictwem kasztelanii nysko-otmuchowskiej na przetomie XIII i XIV wieku, „Sobótka”, 2, 1968, s. 181-197, szczeg. s. 190.
} 
również wstępna analiza map z XIX w., które w takich wsiach pokazują często pola umieszczone w blokach. Inaczej wygląda sytuacja wsi w górskich dolinach na zachodzie badanego obszaru, gdzie również występowały włóki zwyczajne. Tu wyraźnie doliny były zbyt wąskie, aby umożliwić stworzenie regularnych łanów.

Źródła pisane rzadko pozwalają dostrzec tego typu struktury; można je natomiast często zobaczyć na starych mapach, z których najstarsze znane nam pochodzą dopiero z XVIII w. Cenniejsze są dla nas jednak mapy topograficzne, przede wszystkim tzw. Messtischblätter z pocz. XX w., na których widać jeszcze często stare struktury osad i pól. Osobnym źródłem są mapy rysowane z okazji separacji na pocz. XIX w., pokazujące stare struktury pól i osad. W naszym przypadku zostały one opracowane - niestety tylko dla części polskiej księstwa nyskiego - przez Halinę Szulc $^{34}$. Wraz z odwolaniem się do map historycznych przechodzimy do analizy źródeł niepisanych, które mogą być niezmiernie użyteczne w rekonstrukcji genezy osadnictwa.

Punktem wyjścia do odtwarzania procesów osadniczych powinna być geomorfologiczna analiza terenu, czyli badanie jego rzeźby, wysokości, jakości ziemi, wcześniejszej dystrybucji lasów i terenów niezalesionych. Niestety nie mieliśmy do dyspozycji dokładnych map geomorfologicznych całego biskupiego księstwa nyskiego ${ }^{35}$, dlatego stworzyliśmy mapę jakości gleb na podstawie pochodzącego z XVIII w. opisu Śląska autorstwa Friedricha Alberta Zimmermanna ${ }^{36}$, na której na wysokości ok. $250 \mathrm{~m}$ oznaczyliśmy poziomicę, która według Pfitznera stanowiła granicę między terenami starego osadnictwa a ziemiami skolonizowanymi w XIII w. ${ }^{37}$ Mapa ta pokazuje, że najlepsze do osiedlania tereny znajdowały się na północ od Nysy i Otmuchowa, gdzie przeważają ziemie lessowe ${ }^{38}$. Tereny położone na północ od

34 H. Szulc, Typy wsi Śląska Opolskiego na początku XIX wieku i ich geneza, Warszawa 1968.

35 W publikacji Antoniego Musztyfagi pojawia się użyteczna mapa geomorfologiczna. Przedstawia ona jednak niestety tylko polską część biskupiego księstwa nyskiego. Zob. A. Musztyfaga, Ze studiów, dod. między s. 196 i 197.

36 F.A. Zimmermann, Beyträge zur Beschreibung von Schlesien, t. 3, Brieg 1784, s. 256, 263.

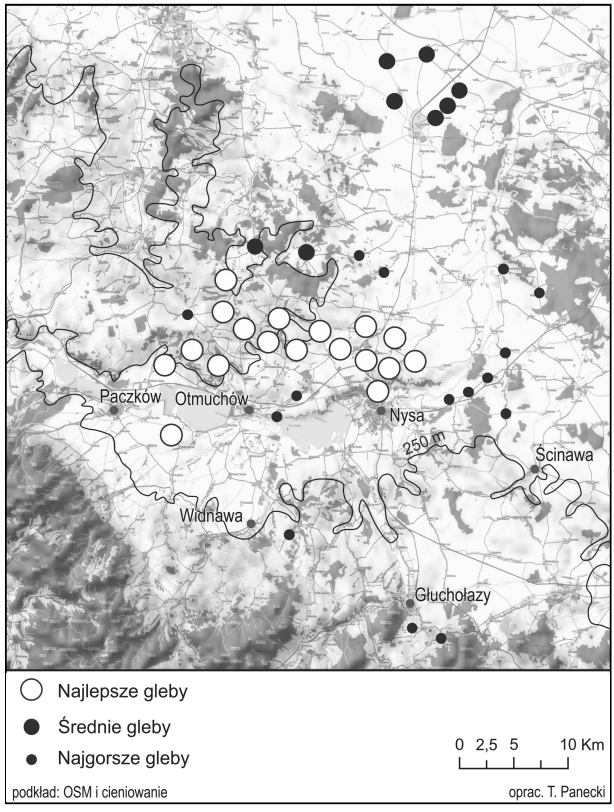

Mapa 8. Jakość gleb

wspomnianych wcześniej ziem mają zaś ziemie gorszej albo średniej jakości.

Mapa znalezisk, choć stworzona na podstawie starszych opracowań, potwierdza wyniki wyciągnięte z mapy gleb, gdyż znaleziska z okresu przedkolonizacyjnego znajdują się prawie wyłącznie na terenach z glebami lepszej jakości ${ }^{39}$. Prezentowana mapa jest jednak niekompletna, ponieważ naniesiono na nią tylko znaleziska datowane do XIII w. Można jednakże domniemywać, że wyniki najnowszych badań archeologicznych wniostyby niewiele dodatkowych informacji, gdyż stanowiska archeologiczne koncentrują się

37 J. Pfitzner, Besiedlungs-, Verfassungs- und Verwaltungsgeschichte, s. 35-39.

38 Próba analizy stosunku rodzajów łanów do jakości gleby dla polskiej części biskupiego księstwa nyskiego: A. Musztyfaga, Ze studiów, s. 195-197.

39 Niestety wyniki najnowszych prac wykopaliskowych i badań terenowych nie zostały jeszcze opublikowane. Z powodu braku dostępu do danych projektu Archeologiczne Zdjęcie Polski nasze mapy opierają się na starym opracowaniu z lat 70. ubiegłego wieku, które wymienia dość dużo znalezisk niedatowanych. J. Kaźmierczyk, K. Macewicz, S. Wuszkan, Studia i materiały do osadnictwa Opolszczyzny wczesnośredniowiecznej, Opole 1977. Zob. też K. Jaworski, Grody w Sudetach (VIII-X w.), Wrocław 2005. Z czeskiej części księstwa aktualnie nie są znane stanowiska archeologicznie z naszego okresu. 
na obszarze, na którym możemy badać najstarsze osadnictwo także za pomocą innych źródel.

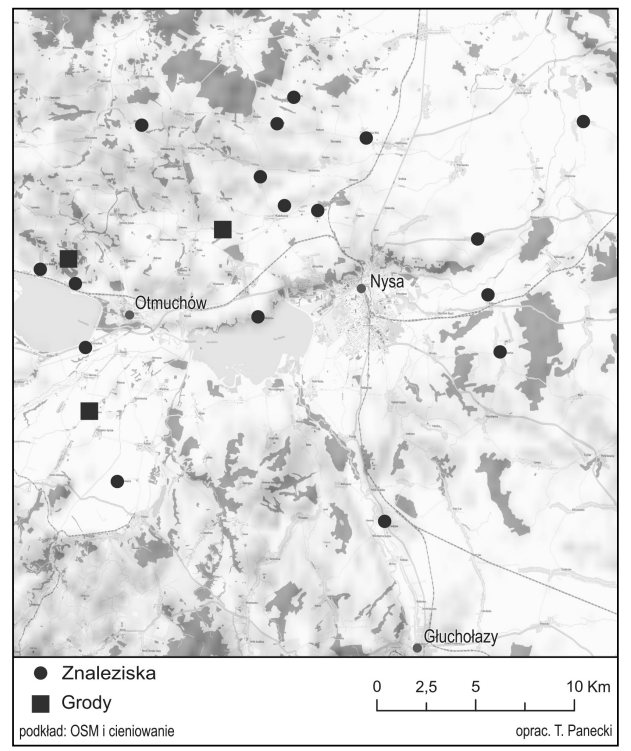

Mapa 9. Znaleziska sprzed XIII w.

Dużo informacji dostarczają również toponimy ${ }^{40}$. Na potrzeby rekonstrukcji osadnictwa przedkolonizacyjnego słowiańskie nazwy miejscowości zostały podzielone na tzw. nazwy pierwotne i wtórne ${ }^{41}$.Za pierwotne uważamy przede wszystkim nazwy dzierżawcze typu Godkowice (Guttwitz) czy Lubiatów (Lobedau). Wskazują one z dużym prawdopodobieństwem na stare osadnictwo słowiańskie. Za wtórne nazwy miejscowości uważamy natomiast te utworzone od apelatywów, jak na przykład Buków (Baucke), które na początku mogły być nazwami terenowymi i dopiero wtórnie, w wyniku kolonizacji, stały się nazwami osad.

40 Toponomastyka Śląska jest dosyć dobrze opracowana. W naszej pracy korzystaliśmy przede wszystkim z tytułów: Stownik etymologiczny nazw geograficznych Śląska, t. 1-15, red. S. Rospond i in., Warszawa i in. 1970-2011 (obecnie do Wrzes); Nazwy miejscowe Polski: historia - pochodzenie - zmiany, t. 1-9, red. K. Rymut, Kraków 1996-2013; Mistní jména na Moravě a ve Slezsku, t. 1-2, [red.] L. Hosák, R. Šrámek, Praha 1970-1980.

410 rozróżnianiu nazw pierwotnych i wtórnych zob. W.H. Fritze, Ortsnamenkunde und Landesgeschichte in ostdeutschen Ländern - Probleme der Namenkontinuität, w: Deutsch-slawische Namenforschung, Hrsg. H.-B. Harder, Marburg (Lahn) 1981, s. 1-39.
Nazwy miejscowości jednoznacznie wskazujące na osadnictwo słowiańskie znaleźć można szczególnie w okolicach Otmuchowa. Germańskie, zwłaszcza gdy występują na dużym obszarze, wskazują na jego kolonizację przez ludność niemiecką.

Sytuacja nie jest jednak tak jednoznaczna, jak wydawałoby się na podstawie powyższego podziału. Na badanym obszarze dość dużo miejscowości ma nazwy hybrydalne, np. Wilemowice (Schützendorf) lub Karlowice (Karlowitz),

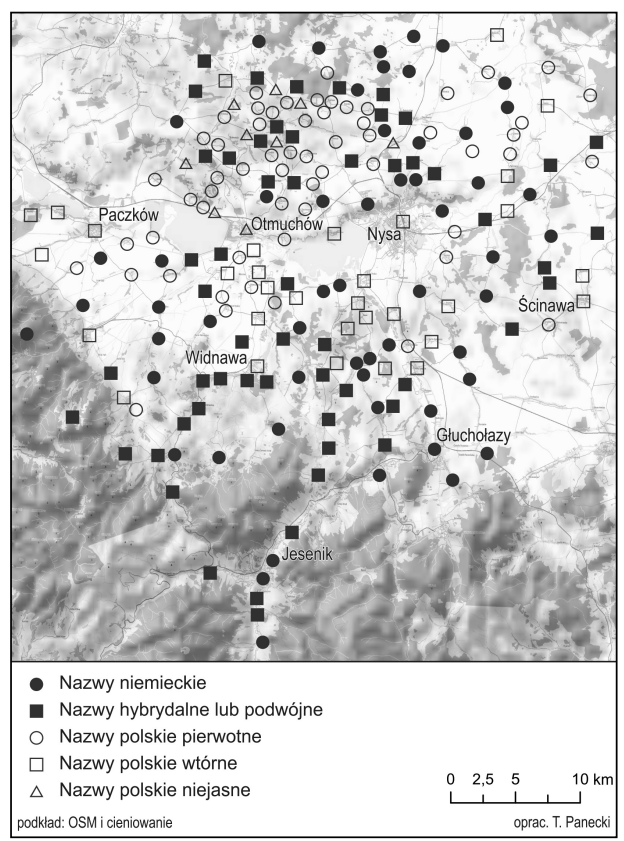

Mapa 10. Nazewnictwo w księstwie nyskim

albo zostały one opisane w źródłach zarówno za pomocą nazwy słowiańskiej, jak i niemieckiej, np. Jessenitza vulgariter Hermannsdorf (Jasienica Dolna / Nieder Hermsdorf). To pokazuje, że czasami nazwa niemiecka zastąpiła polską, a mimo to ludność miejscowa dalej używała starej lub nowa nazwa niemiecka została spolonizowana. Wszystkie te nazwy są cennymi źródłami do zrozumienia charakteru sąsiedztwa i wzajemnego oddziaływania polskich i niemieckich osadników. Dużo nazw polskich było z czasem germanizowanych przez dopasowanie do wymowy niemieckiej. 
Ten toponomastyczny krajobraz został gwałtownie zmieniony dopiero $\mathrm{w} \mathrm{XX}$ w.: najpierw w latach 30. niemieccy urzędnicy zmienili część polskich nazw na germańskie, niezwiązane $\mathrm{z}$ historią konkretnych miejscowości, a potem, po wojnie polska komisja URM zrekonstruowała stare toponimy słowiańskie (np. Pillwösche stała się Białowieżą) oraz wymyślała nowe dla wsi, które dotąd zawsze miały nazwy niemieckie.

\section{Rekonstrukcja kolonizacji i modernizacji terytorium przy wykorzystaniu map tematycznych: od kasztelanii otmuchowskiej do ziemi biskupa Otmuchów-Nysa}

Aby pokazać możliwości pracy z mapami tematycznymi, wybraliśmy dwa obszary pozbawione bogatej bazy źródłowej: tereny między Nysą i wsiami lokowanymi na północno-wschodniej krawędzi kasztelanii oraz tereny na północ od Otmuchowa. Analizując dane naniesione na mapy celem wyjaśnienia genezy osadnictwa, na pierwszym obszarze można dostrzec następujące cechy charakterystycznie: 1 . lekka przewaga nazw niemieckich nad polskimi oraz podwójnymi lub hybrydalnymi; 2 . niewiele znalezisk słowiańskich; 3. przewaga łanów flamandzkich nad włókami zwyczajnymi; 4. kompletny brak łanów leśnych. $\mathrm{Na}$ pocz. XIV w. wsie na tym obszarze przynależały administracyjnie i sądownie do terra Neisse, a niektóre $z$ nich płacily dziesięcinę jeszcze według starego zwyczaju; w mlodszym rejestrze mają one przeważnie prawo polskie. Przekształcenie tych wsi z prawa polskiego na niemieckie byto prawdopodobnie niekompletne lub nie miało charakteru długotrwałego.

Na zachód od wsi Rzymiany (Reimen) i Czarnolas (Petersheide) znajdował się las graniczny, a obok niego słabo zaludniona strefa przejściowa prowadząca do gęsto zamieszkanego obszaru starego osadnictwa. Las graniczny został skolonizowany przeważnie przez ludność niemiecką, zaś strefa przejściowa była zamieszkana przez ludność polską i później także przez nią kolonizowana. Kościoły z prawem do dziesięciny powstały w nowych wsiach: Szklary (Gläsendorf) na północy i Lipniki (Lindenau) na zachodzie oraz we wsi Lasowice (Lasswitz) lokowanej na prawie niemieckim.
Wszystkie te miejscowości z łanami flamandzkimi lub leśnymi na zachodnim krańcu kasztelanii otmuchowskiej, która należy do terenów starego osadnictwa, podlegaly na pocz. XIV i w XV w. miastu na prawie niemieckim - Nysie, podobnie jak wyżej wymienione wsie między Nysą i strumieniem Rimane.

Inaczej prezentuje się obraz na północ od Otmuchowa, gdzie grupa bardzo małych osad, nadal mających prawo polskie, podlegała starej siedzibie kasztelanii w Otmuchowie, która dopiero w XIVw. otrzymała prawo niemieckie. Ten obszar tradycyjnego osadnictwa był na pocz. XIVw. otoczony nowoczesnymi strukturami terra Nyssensis ${ }^{42}$. Przekształcenie terenów kasztelanii zaczęło się więc od jej obszarów granicznych. W dystrykcie otmuchowskim $\mathrm{z}$ wsiami na prawie polskim (jeszcze w XV w.), które znajdowały się przede wszystkim na urodzajnych glebach położonych pomiędzy rzeką Nysą a okolicami lasu przy wsi Biechów (Bechau), koncentruje się kilka znalezisk archeologicznych datowanych na okres przed XIII w. - wśród nich dwa grodziska - oraz kilka trudnych do wyjaśnienia, a więc prawdopodobnie bardzo starych nazw miejscowości i nazw pierwotnych. Rejestr z XIV w. pokazuje na tym obszarze mnóstwo wsi z włókami zwyczajnymi (w przeciwieństwie do łanów leśnych i flamandzkich przeważające przy lokowaniu lub modernizacji starych osad) oraz gęstą sieć małych wsi i dworów istniejących jeszcze w erze nowożytnej. Poza kościołem w Otmuchowie dla części północnej omawianego obszaru powstał jeszcze kościół z prawem do dziesięciny w Karłowicach Wielkich (Groß Karlowitz), co również można interpretować jako ślad wcześniejszej kolonizacji.

Obszar znajdujący się poza lasem granicznym, na poludniowy zachód od Otmuchowa ma natomiast następujące cechy: 1 . niewielka liczba znalezisk słowiańskich; 2 . przewaga nazw słowiańskich nad niemieckimi oraz podwójnymi i hybrydalnymi; 3 . dominacja na pocz. XIV w. wsi $\mathrm{z}$ łanami flamandzkimi lub włókami zwyczajnymi; 4. istnienie osady targowej niebędącej centrum własnego dystryktu. Na tym obszarze przy

\footnotetext{
42 Lib. fund., s. 4-8.
}

\section{I4 studia Geohistorica • Nr 03. 2015}


starym grodzisku Ratnowice (Rathmansdorf) znajdowała się wieś na prawie polskim z kościołem uprawnionym do dziesięciny. Kolejny kościół z tym prawem ulokowany był w pobliżu wsi Kałków (Kalkau). Wsie na prawie niemieckim przynależały przez dłuższy czas do dystryktu Vidnavy. Ogólnie rzecz biorąc, rysuje się obraz terenów, które zostały przekształcone, zachowując jednak stosunkowo dużo starszych struktur. Nowoczesnej rozbudowy w kierunku południa księstwo doświadczyło podczas tworzenia nowego wójtostwa Vidnavy, stanowiącego serce dystryktu pod tą samą nazwą z pocz. XIV w.

Interdyscyplinarna metoda pracy za pomocą map pozwala dojść do nowych wniosków nawet w przypadku, kiedy baza źródeł pisemnych jest bardzo bogata. W 1975 r. historyk Walter Kuhn, który opierał się przede wszystkim na dokumentacji pisanej (i chyba także stereotypach narodowych), widział tylko kontrast pomiędzy polskimi i niemieckimi formami, ignorując wszelkie przejściowe ${ }^{43}$. Trzeba stwierdzić, że naprawdę istnieje wyraźny kontrast między tworzącymi się w efekcie niezaplanowanych działań struk- turami przeważającymi na północ od Otmuchowa i zaplanowanymi osiedlami w terenach byłej przesieki i na wysokości $250 \mathrm{~m}$ n.p.m. Te pierwsze cechuje występowanie nazw pierwotnych, prawa polskiego, przynależności do starych centrów sądowych i administracyjnych w Otmuchowie, włók zwyczajnych i znalezisk archeologicznych; drugie zaś - przewaga nazw niemieckich albo podwójnych, prawa niemieckiego, przynależność do nowych centrów administracyjnych, wsi leśno-łanowych lub ulicówek z łanami flamandzkimi. Dokładniejsza analiza, możliwa dzięki wykorzystaniu map, pozwala jednak dostrzegać między tymi dwoma obszarami o wyraźnie odmiennych strukturach rozległe tereny, na których miała miejsce zarówno kolonizacja, jak i modernizacja starych struktur, np. na poludnie od Otmuchowa, gdzie znajdują się wsie z włókami zwyczajnymi i flamandzkimi łanami z przewagą nazw słowiańskich, które na pocz. XIV w. należały administracyjnie do nowego centrum Vidnavy, ponieważ pobliski ośrodek miejski Otmuchów nie miał jeszcze prawa niemieckiego.
43 „Die Erschließung des Neisser Landes ist durch den Reichtum an schriftlichen Quellen, durch die Schärfe, in der hier deutsche und polnische Formen einander noch im heutigen Siedlungsbild gegenüberstehen, und überdies durch die Dramatik des späteren Kampfes um den Grenzwald zwischen Herzog und Bischof ein Paradebeispiel für die siedlungsmäßige Auseinandersetzung der beiden Völker im 0sten". W. Kuhn, Herzogs- und Adelssiedlung, s. 89-96. 


\section{Bibliografia}

Źródła

Engelbert K., Quellen zur Geschichte des Neisser Bistumslandes auf Grund der drei ältesten Neisser Lagerbücher, Würzburg 1964 (Quellen und Darstellungen zur schlesischen Geschichte, 10).

Liber fundationis episcopatus Vratislaviensis, Hrsg. H. Markgraf, J.W. Schulte, Breslau 1889 (Codex diplomaticus Silesiae, 14).

Regesten zur schlesischen Geschichte, t. 1-4, Hrsg. C. Grünhagen, K. Wutke, Breslau 1884-1892 (Codex diplomaticus Silesiae, 7, 1-3, 16).

\section{Mapy}

Karte des Deutschen Reiches, skala 1:100 000, Institut für Angewandte Geodäsie, Berlin 1958, Großblatt 116: Glatz - Münsterberg, 127: Leobschuetz - Ratibor - Freudenthal Hultschin.

Topographische Karte des Deutschen Reiches, skala 1:25 000 [Messtischblätter], Berlin 19381942 (Preußische Landesaufnahme 1883,

\section{Opracowania}

100 Jahre Landesgeschichte (1906-2006). Leipziger Leistungen, Verwicklungen und Wirkungen, Hrsg. E. Bünz, Leipzig 2012 (Schriften zur sächsischen Geschichte und Volkskunde, 38).

Borek H., Górny Ślask w świetle nazw miejscowych, Opole 1988.

Fritze W.H., Eine Karte zum Verhältnis der frühmittelalterlich-slawischen zur hochmittelalterlichen Siedlung in der Ostprignitz, w: Germania Slavica II, Hrsg. W.H. Fritze, Berlin 1981 (Berliner Historische Studien, 4), s. 41-92.

Fritze W.H., Ortsnamenkunde und Landesgeschichte in ostdeutschen Ländern - Probleme der Namenkontinuität, w: Deutsch-slawische Namenforschung, Hrsg. H.-B. Harder, Marburg (Lahn) 1981, s. 1-39.

Fritze W.H., Schich W., Vorkoloniale und hochmittelalterliche Besiedlung der Zauche und des Hohen Teltow, Berlin 1977 (Historischer Handatlas von Brandenburg und Berlin, 4, 56).

z późniejszymi zmianami): 5467 (ark. Kamenz), 5468 (ark. Lindenau), 5469 (ark. Bechau), 5470 (ark. Bösdorf), 5567 (ark. Reichenstein), 5568 (ark. Patschkau), 5569 (ark. Neisse West), 5570 (ark. Neisse Ost), 5568 (ark. Ober Hermsdorf), 5569 (ark. Kaindorf), 5670 (ark. Ziegenhals).

Szulc H., Atlas historyczny wsi w Polsce, Warszawa 2002.

Gąsiorowski A., „Districtus” w Wielkopolsce początków XIV wieku ( $Z$ zagadnień zarzadu terytorialnego Polski średniowieczniej), „Roczniki Historyczne", 32, 1966, s. 173-193.

Das Havelland im Mittelalter. Untersuchungen zur Strukturgeschichte einer ostelbischen Landschaft in slawischer und deutscher Zeit, Hrsg. W. Ribbe, Berlin 1987 (Germania Slavica, 5; Berliner Historische Studien, 13).

Irgang W., Schlesien im Mittelalter. Siedlung Kirche - Urkunden. Ausgewählte Aufsätze, Marburg 2007 (Materialien und Studien zur Ostmitteleuropa-Forschung, 17).

Jaworski K., Grody w Sudetach (VIII-X w.), Wrocław 2005.

Jurek T., Ryczyn biskupi. Studium z dziejów Kościota polskiego $w X I$ w. „Roczniki Historyczne", 60, 1994, s. 21-66.

Kaźmierczyk J., Macewicz K., Wuszkan S., Studia i materiaty do osadnictwa Opolszczyzny wczesnośredniowiecznej, Opole 1977. 
Kuhn W., Flämische und fränkische Hufe als Leitformen der mittelalterlichen Ostsiedlung, w: tenże, Vergleichende Untersuchungen zur mittelalterlichen Ostsiedlung, Köln-Wien 1973 (Ostmitteleuropa in Vergangenheit und Gegenwart, 16), s. 1-51 (wyd. 1: 1960).

Kuhn W., Herzogs- und Adelssiedlung im Neisser Bistumsland, w: tenże, Neue Beiträge zur schlesischen Siedlungsgeschichte. Eine Aufsatzsammlung, Sigmaringen 1984 (Quellen und Darstellungen zur schlesischen Geschichte, 23), s. 89-101 (wyd. 1: 1975).

Kuhn W., Siedlungsgeschichte Oberschlesiens, Würzburg 1954.

Menzel J., Stadt und Land in der schlesischen Weichbildverfassung, w: Die mittelalterliche Städtebildung im südöstlichen Europa, Hrsg. H. Stoob, Köln-Wien 1977 (Städteforschung, A, 4), s. 19-38.

Mistní jména na Moravě a ve Slezsku, t. 1-2, [red.] L. Hosák, R. Šrámek, Praha 19701980.

Musztyfaga A., Ze studiów nad osadnictwem kasztelanii nysko-otmuchowskiej na przetomie XIII i XIV wieku, „Sobótka”, 2, 1968, s. 181-197.

Nazwy miejscowe Polski: historia - pochodzenie - zmiany, t. 1-9, red. K. Rymut, Kraków 1996-2013.

Pfitzner J., Besiedlungs-, Verfassungs- und Verwaltungsgeschichte des Breslauer Bistumslandes, t. 1: Bis zum Beginn der böhmischen Herrschaft, Reichenberg 1926.

Schich W., Germania Slavica. Die ehemalige interdisziplinäre Arbeitsgruppe am Friedrich-Meinecke-Institut der Freien Universität Berlin, „Jahrbuch für die Geschichte Mittel- und Ostdeutschlands", 48, 2002, s. 269-297.

Schich W., Zum Verbältnis von slawischer und hochmittelalterlicher Siedlung in den Land- schaften Zauche und Teltow, „Jahrbuch für die Geschichte Mittel- und Ostdeutschlands", 26, 1977, s. 53-85.

Scholz B.W., Das geistliche Fürstentum Neisse. Eine ländliche Elite unter der Herrschaft des Bischofs (1300-1650), Köln i in. 2001 (Forschungen und Quellen zur Kirchen- und Kulturgeschichte Ostdeutschlands, 42).

Stownik etymologiczny nazw geograficznych Śla$s k a$, t. 1-15, red. S. Rospond i in., Warszawa $\mathrm{i}$ in. 1970-2011.

Stownik starożytności stowiańskich, red. G. Labuda, Z. Stieber, t. 1-8, Wrocław i in. 19611996.

Stolle F., Das antiquum Registrum des Breslauer Bistums, eine der ältesten Geschichtsquellen, "Zeitschrift des Vereins für die Geschichte Schlesiens", 60, 1926, s. 133-156.

Strzelczyk J., „Germania Slavica”, „Slavia Occidentalis", 37, 1980, s. 178-180.

Strzelczyk J., Problemy badań nad zachodnia peryferia osadnictwa stowiańskiego $w$ Niemczech, w: Stowiańszczyzna potabska między Niemcami a Polską, red. J. Strzelczyk, Poznań 1981, s. 183-199.

Strzelczyk J., Średniowieczna Brandenburgia (Przeglad nowszych publikacji), „Studia Historica Slavo-Germanica”, 10, 1981, s. 159198.

Szulc H., Typy wsi Ślaska Opolskiego na początku XIX wieku i ich geneza, Warszawa 1968.

Wółkiewicz E., Patrimonium sancti Iohannis. U początków wtadztwa biskupiego w ziemi otmuchowsko-nyskiej, w: Milicz. Clavis Regni Poloniae. Gród na pograniczu, red. J. Kolenda, Wrocław 2008, s. 225-234.

Zientara B., Henryk Brodaty i jego czasy, Warszawa 1997.

Zimmermann F.A., Beyträge zur Beschreibung von Schlesien, t. 3, Brieg 1784. 


\section{Structural Transformations in Silesia Caused by Colonization on an Example of the Bishop's Duchy of Nysa}

\section{Summary}

In Silesia colonization with German law began in the $13^{\text {th }}$ century and radically redesigned the structures of the country contributing significantly to demographic changes. This process can be observed particularly well in the duchy of Nysa (Neiße), where the sources are outstandingly abundant. The starting point for the development of the country Neiße was the castellany Otmuchów (Ottmachau) where archaeological finds dated before the $13^{\text {th }}$ century are concentrated north of the eponymous castle. A tax roll called Liber fundationis from around 1300 shows in this space a complex of about 40 small villages with Polish place names, whose inhabitants lived under Polish law and gave tithes by the Polish habit. In con- trast, the areas situated above 250 meters above sea level are dominated by settlements in forest clearings with Waldhufen having almost exclusively German place names. Between these two clearly distinguishable zones the same source records over 60 villae Teutonicales that had obviously been inhabited not only by Germans. The mapping of archaeological remains, types of place names and further information provided by the written sources allow not only to seize more precisely the changes in economy, law and in the settlement pattern, but also the coexistence and cooperation between the Polish and German settlers in the process of colonization in the duchy of Nysa.

Słowa kluczowe: Germania Slavica, interdyscyplinarność, Śląsk, biskupie księstwo nyskie, kolonizacja, prawo niemieckie, zmiany etniczne

Keyw ords: Germania Slavica, interdisciplinarity, Silesia, duchy of Nysa, colonization, German law, ethnic changes

prof. dr hab. Winfried Schich - mediewista, emerytowany profesor Uniwersytetu Humboldta w Berlinie, od 2007 r. członek Polskiej Akademii Umiejętności w Krakowie, długoletni członek zarządu Berlińskiej Komisji Historycznej (Historische Kommission zu Berlin). Zainteresowania badawcze: historia regionalna, historia miasta, stosunki słowiańsko-germańskie, historia osadnictwa, historia ekonomiczna zakonu cystersów

dr Joachim Stephan - mediewista, obronił doktorat na Uniwersytecie Humboldta w Berlinie, pracownik Uniwersytetu im. Adama Mickiewicza w Poznaniu, członek Berlińskiej Komisji Historycznej (Historische Kommission zu Berlin). Zainteresowania badawcze: historia regionalna, stosunki słowiańsko-germańskie, historia zakonu krzyżackiego w Prusach, historia społeczna (joachimstephan@gmx.de) 